\title{
INFORMATIZATION OF THE QUALITY OF MEDICAL CARE IN THE MANAGEMENT OF THE MEDICAL SERVICE OF THE FEDERAL PENITENTIARY SERVICE OF RUSSIA
}

\author{
Gregory Blagodatsky \\ Information Systems Department \\ Izhevsk State Technikal Uneversity, ISTU \\ Izhevsk, Russia \\ blagodatsky@gmail.com \\ Maxim Gorokhov \\ Information Systems Department \\ Chief Researcher Research Institute of the Federal Service \\ for the Execution of Sentences of Russia \\ Izhevsk, Russia \\ insys2005@mail.ru
}

\author{
Dmitriy Ponomarev \\ Information Systems Department \\ Izhevsk State Technikal Uneversity, ISTU \\ Izhevsk, Russia \\ docmedsb@yandex.ru \\ Sergey Ponomarev \\ Information Systems Department \\ Research Institute of the Federal Service for the Execution \\ of Sentences of Russia, the head of the branch city of \\ Izhevsk \\ Izhevsk, Russia \\ docmedsb@yandex.ru
}

\author{
Sergey Vologdin \\ Information Systems Department \\ Izhevsk State Technikal Uneversity, ISTU \\ Izhevsk, Russia \\ vologdin-sv@mail.ru
}

\begin{abstract}
This article is reviews some aspects of information management in health service. The concept of "quality of medical care" is considered. The features of the unified information space is represented. The conceptual scheme of management system with the use of artificial intelligence is suggested. The algorithm of neural network learning using back-propagation procedure is analyzed.
\end{abstract}

Keywords - health service, quality of medical care, information technology, common information space, artificial intelligence, neural networks

\section{INTRODUCTION}

The contemporary information technologies allow to manage complex economic processes, to solve problems of the current, medium and long-term planning, to carry out effective horizontal and vertical interaction. This is especially true in the health service [1]. Currently, a huge number of demands are place on health facilities in the field of professional activity and thus we have some problems [2]. A practical solution to most problems is impossible without informatization of health care. This is stated in the concept of long-term socio-economic development of the Russian Federation until 2020. [3]
Information technologies improve the efficiency of processes management, are used to reduce the costs, attach flexibility to different processes and open more opportunities for development. The transition to an information society makes a completely new approach to solving problems in various sectors, including the health service. [4]

\section{THE MAIN PART}

Information systems that can optimize the management of social structures become increasingly complex in their historical development.

They have gone from simple tracking of the current state to corporate information systems that are able to independently keeping records and optimization of management processes, aligning them with the environmental conditions.

The problem of the health service informatization was considered by many scientists and health officials, among whom could be highlighted the work of A.I. Vyalkova [5], J.W. Kirklin [6], R. Bellman [ 7 ], Sheppard L. [8, 9 ], etc.

The health service informatization in the Soviet Union and Russia began in 1950 - 1960s. Many famous names of doctors, 
biologists, psychologists, mathematicians, engineers are inscribed in its history. In the mid - 1970s a system for coordinating work for the introduction of informatics methods and computer equipment in medical practice at the state level was created. The contemporary history of Russian Federation health service informatization began in 2008 with the establishment within the Ministry of Health and Social Development Department of Information Technology and Communications, with the head of O.V. Simakov. Since this moment, work has began on develop the Concept of creating a Common State Information Health Service systems [10].

The purpose of the health service informatization is to increase the availability and quality of medical care. The basis of the automation process of information interaction between institutions and organizations of the health service system, health authorities of the Russian Federation, as well as the federal executive authorities, ensuring the implementation of the state policy in the field of health care.

The problem of health care quality improving is relevant not only for Russian Federation health service [11]: 30-50 \% of health service costs in the U.S. accounts for low-quality medical care [12].

Many different definitions of the quality assurance concept are usually to be found in worldwide literature. This way A. Donabedian [13,14 ] defines this concept as "all activities aimed at ensuring, maintaining and improving the medical care quality". H.V. Vuory [15] said that quality assurance is actual dimension with the adoption of measures aimed at changing the production of medical services in the desired direction." According to the definition, given by R.N. Palmer [16], the concept of quality is "the measurement process of quality, evaluation and analysis of violations and adoption of measures to improve the work and then re-measuring the quality in order to determine the improvement achieved. This is the systematic, cyclical activity using standards ".

To date, most authors agree on the need for a system of concepts and indicators, each of which would be revealed different aspects of "medical care" concept in relation to the specific conditions of the health service, and they generally would create a clear picture of the medical care quality at any level $[16,17]$.

In the context of the need to monitor and analyze a large number of divergent information flows arising in the implementation of measures for medical institutions management, the questions arise as to the establishment of a trust a single information space.

In addition to this condition, the information collection system should be operational. Besides, the system should provide an opportunity to collect and analyze information on the different levels. It should manage the all health service system, assess the efficiency, manage the course of measures and the reception of medicines, equipment, test kits, etc. Given that health care has all the properties of the goods and customer services, it is possible to use special information systems, in particular ERP and CRM systems to solve the described problems.
Thus, ERP-systems (literally enterprise resource planning systems) can be used to optimize the "doctor -patient" interaction. This way the "enterprise resource " may be considered as medical staff work, medicines, medical equipment, etc. CRM- systems - are the systems of interaction management with customer [18].

The basic process of any managed structure has three components in its base: the main activity planning and organization, the basic process and its movement, the main activities control. Main connecting process between the management and the basic process is the workflow process that generates a single information environment organization. To describe the process in a formal language use could be made of various pseudo-modeling languages, in particular - UML [19].

High dynamic of changes in the information system operational environment requires high effective in an everchanging problem statements and organizational structures.

Full conceptual scheme of the management system deployment is shown in Fig. 1.

A Web-portal is the integral part of the system. The Webportal implements the distant main process tasks. Server allows to integrate all existing information systems, combining them into a single ERP system [21, 22,23$]$.

Indexes that are obtained by the generalized information system, helps you build quality and reliable mathematical model of integrated assessment. It should be noted that the task of efficiency improving of internal management systems is hard formalized. In view of this, it is necessary to carry out complex expertise for evaluating the management effective. A special role in this expertise may use mathematical approaches, in particular such artificial intelligence methods as artificial neural network.

The neural networks are the mathematical models, as well as their software or hardware implementation, based on the principle of organization and functioning of biological neural networks - networks of nerve cells of a living organism. This method is universal and promising to global problems solving. That area of research requires careful consideration because of its importance.

Among the various structures, full-conducted, fully connected neural networks are definable. In these structures different levels connections between neurons are designed. If this network has one layer, the mechanism of supervised learning aims to minimize the error at the network output. This method is used to a single-layer perceptron training.

In multilayer neural networks, by contrast, the optimum value of the output neuron layer, except the last one, are "in general" unknown. The multilayer neural network cannot be taught, guided only by the values of errors at the network outputs. As a solution to this problem, it is possible to offer the engineering some sets of output signals, corresponding to the input, for each layer of the neural network. This operation is very time-consuming and not always feasible. Another solution is the dynamic adjustment of the weighting coefficients synapses. While configuring the weak links, which vary by a small amount in one direction or another, are selected. 
Modification affecting the output error decrease is stored. This method requires a large calculation.

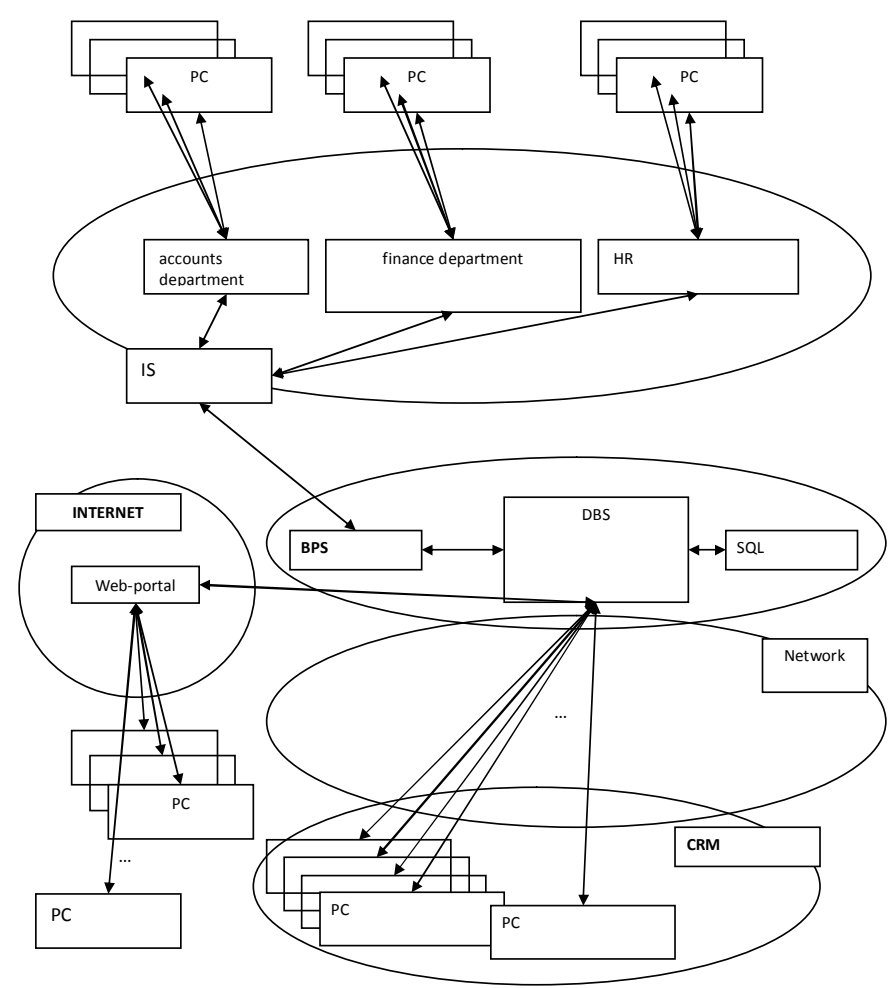

Fig. 1. The concept of system deployment [20]

Last way - is back-propagation algorithm, that has various modifications [24]

Full learning neural network algorithm, that used backpropagation procedure is constructed as follows [25]:

1. To apply for the network inputs one of the possible images in normal operation mode of the neural network when the signals propagate from inputs to outputs, to calculate the values of the past. Recall that

$$
s_{j}^{(n)}=\sum_{i=0}^{M} y_{i}^{(n-1)} w_{i j}^{(n)},
$$

where $-M$ is the number of neurons in the $n-1$ layer with the neuron with a constant output state +1 , specifies the offset;

$$
y_{i}^{(n-1)}=x_{i j}^{(n)},
$$

where $i$ - th input of the neuron $j$ in the $n$ layer.

$$
y_{i}^{(n)}=f\left(s_{j}^{(n)}\right)
$$

where $f()$ - is sigmoid.

$$
y_{q}^{(0)}=I_{q} \text {, }
$$

where $I_{q}-q$ - th component of the input image vector.

2. To calculate $d^{(N)}$ for the output layer. To calculate the changes of weights $\mathrm{D} w^{(N)}$ of $N$ layer.

3 . To calculate $d^{(n)}$ and $\mathrm{D} w^{(n)}$ for all other layers $n=N-1, \ldots, 1$.

4 . To adjust the weights in the neural network $w_{i j}^{(n)}(t)=w_{i j}^{(n)}(t-1)+\Delta w_{i j}^{(n)}(t)$

5 . If the network error is significant, go to step 1. Otherwise - to complete the training.

In step 1 alternately in random order training images are issued to the network, in order to the network, so to speak, do not forget some images as remembering others. From this expression, it follows that when the output $y_{i}^{(n-1)}$ goes to zero, the effective of training is markedly reduced. While binary input vectors are exist, on average half the weight coefficients cannot be adjusted. So the possible values range of the output neurons $[0,1]$ is desirable to move within the $[-0.5,+0.5]$, which is achieved by simple modifications of logistic functions.

For example, the exponential sigmoid is transformed to

$$
f(x)=\frac{1}{1-e^{-a x}}-0.5
$$

Neural networks are quite powerful modeling tool, that are allow to present extremely complex dependencies.

Back-propagation error algorithm is an iterative gradient learning algorithm that is used to minimize the mean square deviation of current from the desired outputs of multilayer neural networks with serial conducts.

\section{CONCLUSIONS}

Any modern corporate system development is always associated with the use of three technologies: management, production and information that interact with each other as a single mechanism that has material, labor and information resources in the input and produces a planned result in output. The role of the information systems in the supply chain management mechanism is to provide a unified information space where information conducts can be organized of any orientation and communication complexity.

The application of unified information system based on the business-processes server and innovative CRM platform allows obtaining consolidated information on performance of all divisions of the health system.

Introduction of the unified health information system that consists of many specialized modules helps in synchronous solution of diagnostic, therapeutic, administrative, financial, statistical, and other tasks. 
In turn, all this ultimately helps to achieve the final goal of the health system - the provision of quality health services

\section{REFERENCES}

[1]. K.A. Romanov, Perevedencev D.A., Perevedencev K.A., Spolohova M.A., "Edinaja integrirovannaja informacionnaja sistema upravlenija medicinskimi uchrezhdenijami ugolovno-ispolnitel'noj sistemy Rossii," The proceedings of IX international scientific conference «Achievement of high school - 2013» Sophia, Bulgaria: «Bjal GRAD-BG» Publishing, 2013 , pp. $55-57$.

[2]. Laktionova, L.V., "Organizacija informacionnogo prostranstva medicinskogo uchrezhdenija. Jelektronnyj nauchnyj zhurnal «Social'nye aspekty zdorov'ja naselenija»," URL: http://vestnik.mednet.ru/content/view/470/30/.

[3]. Rasporjazhenie ot 17 nojabrja 2008 g. №1662-r (v red. rasporjazhenija Pravitel'stva RF ot 08.08.2009 №1121-r) “O koncepcii dolgosrochnogo social'no-jekonomicheskogo razvitija Rossijskoj Federacii do 2020 g.," Sobranie zakonodatel'stva RF, 12.11.2012, vol. 46 , p. 6386.

[4]. K. A. Romanov, M. A. Spolohova, S. B. Ponomarev, "Sovremennye informacionnye tehnologii $\mathrm{v}$ ugolovno-ispolnitel'noj sisteme Rossii," Vestnik Izhevskogo gosudarstvennogo tehnicheskogo universiteta, 2013, vol. 2(58), pp. 134-136.

[5]. Informacionnye tehnologii $\mathrm{v}$ upravlenii zdravoohraneniem Rossijskoj Federacii: Uchebnoe posobie. D-r med. nauk, prof., akademika RAMN A.I. Vjalkova Eds, Moskow: GJeOTAR-Media, 2009, 248 p.

[6]. Kirklin J.W., "System analysis in surgical patients," Glasgo University: publica tion, 1970, vol. 139, p. 23.

[7]. Bellman, R. "Math methods in medicine", (translated from engl.), Moskow: MIR, 1987, 192 p.

[8]. Sheppard L.C., Kirklin J.W. "Cardiac surgical intensive care computer system,” Fed. Proc, 1974, vol. 33, pp. 2326-2328.

[9]. Sheppard L.C., "The computer in the care of critically ills patients," Proc. IEEE, 1979. vol. 67, N 9. pp. 1300-1305.

[10]. Zarubina T.V., "Napravlenija informatizacii zdravoohranenija Rossii na sovremennom jetape," Informacionnoizmeritel"nye i upravljajushhie sistemy, vol. 10, t. 11, 2013, pp. $4-8$.

[11]. International standard ISO 9000. Quality management systems. Fundamentals and vocabulary, 2005. pp. 4-40.

[12]. Acel', E.A., "Upravlenie kachestvom kardiologicheskoj pomoshhi $\mathrm{V}$ period modernizacii zdravoohranenija," Vestnik sovremennoj klinicheskoj mediciny, 2013, vol. 4 (t.6), pp. 41 - 45.

[13]. Donabedian, A., "Twenty years of Research on the Quality of Medical care," Evaluation and the Health professions, 1985, vol. 3. pp. 243-265.
[14]. A. Donabedian, S. Leonard, W. Osenfe, "Models of quality assurance. Memorial Lecture," School of Public Health University of North Carolina in Chapel HiB, 1993, Febr. 26.

[15]. Vuory, H.V., "Quality assurance of health services," Copenhagen, WHO Regional Office for Europe, Public Health in Europe, 1982, vol. 16, pp. 3-8.

[16]. R.H. Palmer, "Confronting Special Implementation Issue: The Epidemiology of Quality Problem in Medicare: New Directions in Quality Assurance," eds. M.S. Donalson, S. Harris-Welling, K.N. Johr. Washington, OC: National Academy Press, 1991, pp. 96-104.

[17]. Peterson, M.C., "A systematic review of outcomes and quality measures in adult patients cared for by hospitalists vs nonhospitalists," Mayo Clin. Proc., 2009, Vol. 84, № 3, pp. 248-254.

[18]. S. B. Ponomarev, M. M. Gorohov, A. V. Serebrennikov, S. G. Loginova, "K voprosu o primenenii informacionnyh sistem dlja optimizacii taktiki vedenija bol'nyh $\mathrm{V}$ mestah lishenija svobody," Intellektual'nye sistemy v proizvodstve, 2007, vol. 2 (10), pp. 100-103.

[19]. A.A. Bas, G.A. Blagodatsky, M.M. Gorokhov, A.V. Korepanov, A.A. Stanovskih, "Information security organization system approach," The Proceedings of the 3-rd forum of yong researches, Izhevsk: Istu Publishing, 2012, pp. 235 -241, WOS:000323583400031.

[20]. Perevedencev D.A., Romanov K.A., Abramova M.A., Blagodatskij G.A., "Proektirovanie integrirovannoj informacionnoj sredy organizacii," Trudy Mezhdunarodnogo Foruma po problemam nauki, tehniki i obrazovanija «III tysjacheletie - novyj mir», Moskow, Akademija nauk o Zemle, 2012, pp. 96-97.

[21]. G.A. Blagodatskij, M.M. Gorohov, D.I. Kazancev, A.A. Stanovskih, "Metody povyshenija konkurentosposobnogo potenciala predprijatija," Problemy sovershenstvovanija mehanizma upravlenija jekonomicheskimi sistemami v sovremennom mire: Sbornik statej Mezhdunarodnoj nauchnoj Internet konferencii, Kazan: KF MOSAP, 2009 , pp. 885 - 903.

[22]. Bas A.A., Blagodatskij G.A., Gorohov M.M., "Razrabotka programmno-instrumental'nyh sredstv planirovanija resursov i upravlenija v social'no-jekonomicheskih sistemah," Vestnik Izhevskogo Gosudarstvennogo Tehnicheskogo Universiteta, 2011, vol. 3 (51), pp. $146-149$.

[23]. Blagodatsky G.A., "The Corporate Information Systems Evolution," International Workshop «Innovation Information Techologies - Theory and Practice», Dresden: Forschungszentrum Dresden-Rossendorf, 2010, pp. 227 - 228.

[24]. Paul J. Werbos, "Backpropagation Through Time: What It Does and How to Do It," Artificial Neural Networks: Concepts and Theory, IEEE Computer Society Press, 1992, pp. 309-319.

[25]. Korotkij S., "Nejronnye seti: algoritm obratnogo rasprostranenija," Saint Petersburg: Piter, 2000, 328 p. 